Portland State University

PDXScholar

$5-1-2011$

\title{
Statistical Comparisons of Watershed-Scale Response to Climate Change in Selected Basins across the United States
}

John Risley

Portland State University

Hamid Moradkhani

Portland State University

Lauren Hay

Steve Markstrom

Follow this and additional works at: https://pdxscholar.library.pdx.edu/cengin_fac

Part of the Civil and Environmental Engineering Commons Let us know how access to this document benefits you.

\section{Citation Details}

Risley, J., Moradkhani, H., Hay, L., \& Markstrom, S. (2011). Statistical Comparisons of Watershed-Scale Response to Climate Change in Selected Basins across the United States. [Article]. Earth Interactions, 15, 26.

This Article is brought to you for free and open access. It has been accepted for inclusion in Civil and Environmental Engineering Faculty Publications and Presentations by an authorized administrator of PDXScholar. Please contact us if we can make this document more accessible: pdxscholar@pdx.edu. 


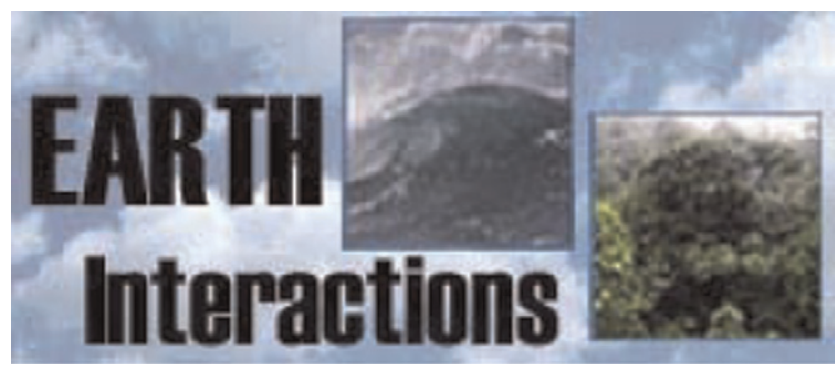

Copyright $@$ 2011, Paper 15-014; 9177 words, 13 Figures, 0 Animations, 6 Tables. http://EarthInteractions.org

\title{
Statistical Comparisons of Watershed-Scale Response to Climate Change in Selected Basins across the United States
}

\section{John Risley*}

U.S. Geological Survey, Portland, Oregon

\section{Hamid Moradkhani}

Civil and Environmental Engineering, Portland State University, Portland, Oregon

\section{Lauren Hay and Steve Markstrom}

\section{U.S. Geological Survey, Denver, Colorado}

Received 18 June 2010; accepted 31 October 2010

\begin{abstract}
In an earlier global climate-change study, air temperature and precipitation data for the entire twenty-first century simulated from five general circulation models were used as input to precalibrated watershed models for 14 selected basins across the United States. Simulated daily streamflow and energy output from the watershed models were used to compute a range of statistics. With a side-by-side comparison of the statistical analyses for the 14 basins, regional climatic and hydrologic trends over the twenty-first century could be qualitatively identified. Low-flow statistics (95\% exceedance, 7-day mean annual minimum, and summer mean monthly streamflow) decreased for almost all basins. Annual maximum daily streamflow also decreased in all the basins, except for all four basins in California and the Pacific Northwest. An analysis of
\end{abstract}

* Corresponding author address: John Risley, U.S. Geological Survey, Oregon Water Science Center, 2130 SW 5th Avenue, Portland, OR 97201.

E-mail address: jrisley@usgs.gov 
Earth Interactions - Volume 15 (2011) - Paper No. 14 • Page 2

the supply of available energy and water for the basins indicated that ratios of evaporation to precipitation and potential evapotranspiration to precipitation for most of the basins will increase. Probability density functions (PDFs) were developed to assess the uncertainty and multimodality in the impact of climate change on mean annual streamflow variability. Kolmogorov-Smirnov tests showed significant differences between the beginning and ending twenty-firstcentury PDFs for most of the basins, with the exception of four basins that are located in the western United States. Almost none of the basin PDFs were normally distributed, and two basins in the upper Midwest had PDFs that were extremely dispersed and skewed.

KEYWORDS: Climate change; Watershed modeling; Streamflow; Snowmelt; Rainfall; Groundwater

\section{Introduction}

Findings from Bernstein et al. (Bernstein et al. 2007) describe how climate change resulting from increasing anthropogenic greenhouse-gas concentrations in the atmosphere will cause spatial and temporal alterations in the distribution of water resources in river drainage basins during the twenty-first century. To analyze potential shifts in water resources, climate output from general circulation models (GCMs) has often been input to hydrologic models that are used to simulate runoff under various emission scenarios. Stewart et al. (Stewart et al. 2004) created regression relations between streamflow timing and precipitation and temperature indices. In their analysis, they used National Center for Atmospheric Research climate model output under a "business as usual" greenhouse-gas emissions scenario (Washington et al. 2000) and projected springtime snowmelt occurring earlier than the historic average across much of western North America for the 1995-2099 period. To assess the effects of potential climate change on mean annual runoff throughout the conterminous United States, Wolock and McCabe (Wolock and McCabe 1999) used a simple water-balance model and output from two atmospheric GCMs. However, their results were uncertain because they were mostly within the range of GCM decade-to-decade variability and GCM model error.

To simulate hydrologic climate changes at a watershed scale, downscaled GCM air temperature and precipitation data can be input to distributed watershed models that simulate streamflow in addition to various water and energy fluxes within a basin. Dibike and Coulibaly (Dibike and Coulibaly 2005) compared two statistical downscaling and hydrologic modeling techniques to simulate runoff in a watershed in northern Quebec, Canada. Both downscaling methods resulted in increased winter low flow and earlier spring high flows, which was consistent with reduced freezing and increasing trends in temperature and snowmelt. Downscaled data from two GCMs were also used to analyze the effects of climate change on the Fraser River basin in British Columbia, Canada, by Morrison et al. (Morrison et al. 2002). In their study, continuous precipitation and temperature data were input to the University of British Columbia watershed model to simulate snowpack accumulation and melting. Although their results predicted a slight increase in mean flow near the end of the twenty-first century, they predicted a significant decrease in mean peak flows that occurred on average 24 days earlier. Hamlet and Lettenmaier (Hamlet and Lettenmaier 1999) statistically downscaled precipitation 
Earth Interactions - Volume 15 (2011) • Paper No. 14 • Page 3

and temperature data from four GCMs to evaluate surface-water response of the Columbia River basin. Using the grid-based Variable Infiltration Capacity (VIC) hydrologic model, climate-change-driven simulations resulted in increased winter streamflow, reduced winter snow accumulation, and reduced spring and summer streamflow. Najafi et al. (Najafi et al. 2010) used five statistical downscaling methods built on a machine learning concept to downscale GCM precipitation to the gauge station level. They used an optimal procedure for climate-predictor selection based on an independent component analysis (Moradkhani and Meier 2010), where both correlation and dependence among predictors are removed, which results in a reduced number of predictors required for downscaling. As an alternative to statistical downscaling, dynamic downscaling with a regional climate model and a hydrologic model was used by Leung and Wigmosta (Leung and Wigmosta 1999) to simulate runoff in the American River and Middle Fork Flathead River in Washington and Montana, respectively. They determined that climate-change impacts on hydrology are region specific and driven by temperature inputs more than precipitation inputs. Although dynamic downscaling has the advantage of considering the physical processes in its modeling framework, its intensive computational demand limits its application. In addition, the existence of bias in regional climate models (RCMs) requires bias correction through statistical postprocessing. Because of these disadvantages, dynamic downscaling still has limited use in hydrologic applications.

The U.S. Geological Survey (USGS) Precipitation-Runoff Modeling System (PRMS), the model that generated the output analyzed in this paper, has become a capable watershed model for analyzing climate-change effects (Leavesley et al. 1992). Dagnachew et al. (Dagnachew et al. 2003) used PRMS to simulate climate and land-use changes in south-central Ethiopia. Chang and Jung (Chang and Jung 2010) used PRMS and precipitation and temperature input from eight GCMs to simulate potential changes in annual, seasonal, and high- and low-flow runoff in 216 subbasins of the Willamette River basin in Oregon for the 2040s and 2080s. Hay et al. (Hay et al. 2011) presented watershed-scale responses to climate change in selected basins across the United States from 2001 to 2099. In their study, they used precipitation and air temperature output from five GCMs as input to a PRMS watershed model for each of their basins. Consecutive sets of 12-yr watershed simulations were then run for the period from 2001 to 2099. Simulated daily output from the watershed models included basin outlet streamflow in addition to various basin water fluxes and storage levels.

This paper provides a comparison of statistical analyses performed on output from hydrologic simulations of 14 watershed models driven by GCM output from Hay et al. (Hay et al. 2011). Interpretation of results presented in this paper is intentionally limited. Watershed and climate processes are complex, even without global climate change. There is always a wide array of individual and combined factors that can explain hydrologic response in a watershed model. Complex geologic controls that are specific to a basin are often in play, and a comprehensive understanding of these local processes was outside the scope of this paper. However, by presenting a side-by-side comparison of statistical results for the 14 basins, it is possible to identify regional climatic and hydrologic patterns. 
Table 1. GCMs used by Hay et al. (Hay et al. 2011). GCM definitions not defined in the text: Bjerknes Centre for Climate Research Bergen Climate Model (BCCRBCM2.0), Commonwealth Scientific and Industrial Research Organisation Mark version 3.0 (CSIRO Mk3.0), Institute of Numerical Mathematics Coupled Model, version 3.0 (INM-CM3.0), and Model for Interdisciplinary Research on Climate 3.2, medium-resolution version (MIROC3.2(medres)).

\begin{tabular}{ll}
\hline \multicolumn{1}{c}{ GCM } & \multicolumn{1}{c}{ Center and country of origin } \\
\hline BCCR-BCM2.0 & Bjerknes Centre for Climate Research, Norway \\
CSIRO Mk3.0 & Commonwealth Scientific and Industrial Research Organization, Australia \\
CSIRO Mk3.5 & Commonwealth Scientific and Industrial Research Organization, Australia \\
IMN-CM3.0 & Institute for Numerical Mathematics, Russia \\
MIROC3.2(medres) & National Institute for Environmental Studies, Japan \\
\hline
\end{tabular}

\section{Background study}

\subsection{Modeling methods}

In their climate-change study, Hay et al. (Hay et al. 2011) used watershed models that had been developed, calibrated, and validated for previous USGS watershed studies for 14 basins in the United States. Of these basins, 12 had models created from PRMS. PRMS is a deterministic, distributed-parameter watershed model developed to evaluate the impacts of various combinations of precipitation, temperature, and land use on streamflow and general basin hydrology (Leavesley et al. 1992). The watershed land surface is discretized into user-defined hydrologic response units (HRUs). Operating on a daily time step, the minimum required input data for a PRMS simulation are daily precipitation and minimum and maximum air temperature. The two remaining basins in Hay et al. (Hay et al. 2011) used models created from the USGS Coupled Ground-water and Surface-Water Flow (GSFLOW), model (Markstrom et al. 2008), which is an integration of PRMS and the USGS Modular Groundwater Flow Model (MODFLOW). Like PRMS, GSFLOW simulations can be made using daily precipitation and minimum and maximum air temperature data as the main data input.

Daily precipitation and air temperature data representing possible future climatechange scenarios needed to run the PRMS and GSFLOW watershed models were derived from GCM output obtained from the World Climate Research Programme's Coupled Model Intercomparison Project phase 3 multimodel dataset archive, which was referenced in the Intergovernmental Panel on Climate Change (IPCC) Fourth Assessment Report (AR4) Special Report on Emission Scenarios (SRES) (Alley 2007). Because of the uncertainty in climate modeling, it was desirable to use more than one GCM to obtain a range of potential future climatic conditions. Hay et al. (Hay et al. 2011) used five GCMs from the IPCC report (Table 1). For each GCM they acquired simulated monthly precipitation and air temperature output data representing three future emission scenarios (Table 2). Of these scenarios, SRES A2 and SRES B1 have the highest and lowest levels of carbon loading in the atmosphere, respectively, and carbon loading for the SRES A1B scenario was in between the two others.

Monthly precipitation and air temperature output from the GCMs for each future emission scenario were downscaled to a daily time step for their use in the watershed models using the following method: The 12-yr period of water years 
Earth Interactions • Volume 15 (2011) • Paper No. 14 • Page 5

Table 2. GCM emission scenarios used by Hay et al. (Hay et al. 2011).

\begin{tabular}{lcl}
\hline GCM scenario & Time period & \multicolumn{1}{c}{ Description } \\
\hline 20C3M & $1988-99$ & $\begin{array}{l}\text { Current conditions. } \\
\text { Very heterogeneous world with high population growth and } \\
\text { slow economic growth. } \\
\text { World with very rapid economic growth, a global population that peaks } \\
\text { in midcentury, and rapid introduction of new and more efficient } \\
\text { technologies balanced across all sources. } \\
\text { Convergent world with low population growth and rapid changes in } \\
\text { economic structure. }\end{array}$ \\
\hline
\end{tabular}

(1 October-30 September) 1988-99 was defined as the current condition for which time series of observed daily precipitation and minimum and maximum air temperature data for all 14 basins existed. Monthly climate-change deltas (percentage changes in precipitation and degree Celsius changes in air temperature) were derived by calculating the change in climate from the current condition 12-yr period to future 12-yr periods simulated by each GCM. Using a 12-yr moving window, starting in 2001 and ending in 2099, eighty-eight 12-yr climatologies were created. For each basin, a total of 1320 scenarios (eighty-eight 12-yr climatologies $\times 3$ emission scenarios $\times 5$ GCMs) were analyzed.

Climate output from each GCM was distributed through grid nodes. For all 14 basins, output from the GCM grid node that was closest to the basin centroid was directly used to compute climate-change deltas. The GCM output was not adjusted for basin elevation. Interpolations based on the basin proximity to other GCM grid nodes were not made.

\subsection{Study basins}

Drainages areas of the 14 basins used in the study by Hay et al. (Hay et al. 2011) ranged from 27 to $9324 \mathrm{~km}^{2}$ (Figure 1 and Table 3). Basin outlet elevations ranged from near mean sea level to over $2400 \mathrm{~m}$ above mean sea level. The basins were also diverse in regards to vegetation and humidity. Based on measured and estimated streamflow for the 1988-2000 water year period, basin yield ranged from 0.002 to $0.0306 \mathrm{~m}^{3} \mathrm{~s}^{-1} \mathrm{~km}^{-2}$ for Starkweather Coulee in North Dakota and Cathance Stream in Maine, respectively. Additional information on the 14 basins is provided below and in Hay et al. (Hay et al. 2011). To better compare the hydrologic statistics, the 14 study basins were grouped into six regions based on climatic, geographic, and physiographic similarity: Pacific Northwest, Sierra Nevada, Rocky Mountains, Midwest, Northeast, and Southeast.

\subsection{Pacific Northwest}

2.2. 1.1. Naches River, central Washington. The Naches River is a tributary of the Yakima River in central Washington on the eastern side of the Cascade Mountains. The study basin historically receives approximately $1000 \mathrm{~mm}$ of precipitation per year and ranges in elevation from 472 to over $1650 \mathrm{~m}$ above mean 


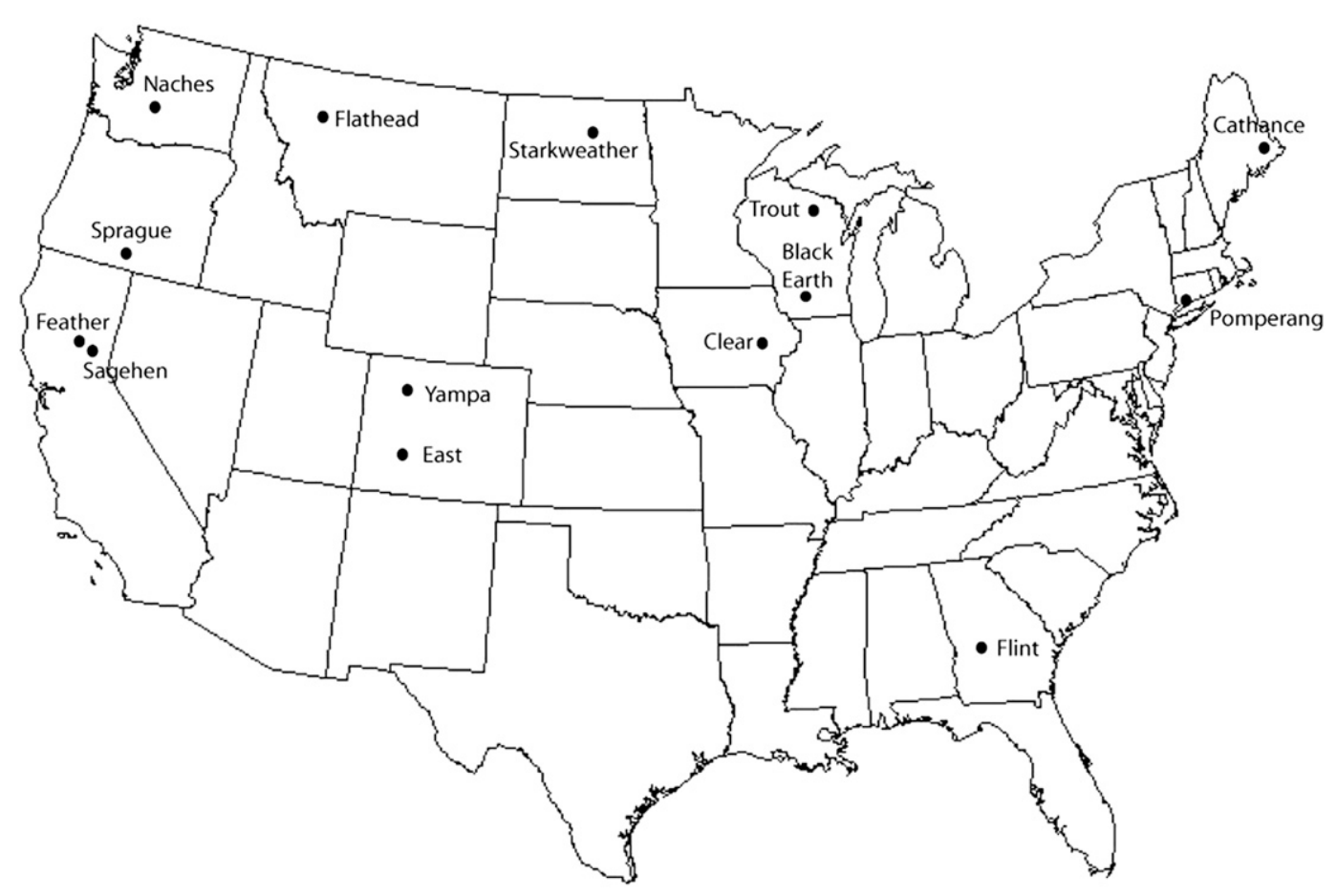

Figure 1. Map showing the location of the study basins.

sea level. Because much of the annual precipitation falls as snow, especially in higher elevations, the highest streamflows typically occur in May in the form of snowmelt.

2.2.1.2. Sprague River, south-central Oregon. Located in south-central Oregon, the semiarid Sprague River study basin has a mean annual precipitation of approximately $500 \mathrm{~mm}$. Historically, between $30 \%$ and $60 \%$ of the annual precipitation is snow, and the highest monthly streamflows typically occur in April. The study basin is $4053 \mathrm{~km}^{2}$ in area and provides approximately $25 \%$ of the inflow to the Upper Klamath Lake.

\subsubsection{Sierra Nevada}

2.2.2. 1. Feather River, northern California. Located on the western slope of the Sierra Nevada mountain range in northern California, the Feather River is a major tributary to the Sacramento River. Elevations in the study basin range from 325 to over $2200 \mathrm{~m}$ above mean sea level, with the historical snow line at approximately $1600 \mathrm{~m}$. At lower elevations, the climate is Mediterranean with warm dry summers and temperate wet winters. Although much of the basin runoff is snowmelt from the upper elevations, winter rain and rain-on-snow events are also common. 
Earth Interactions - Volume 15 (2011) - Paper No. 14 • Page 7

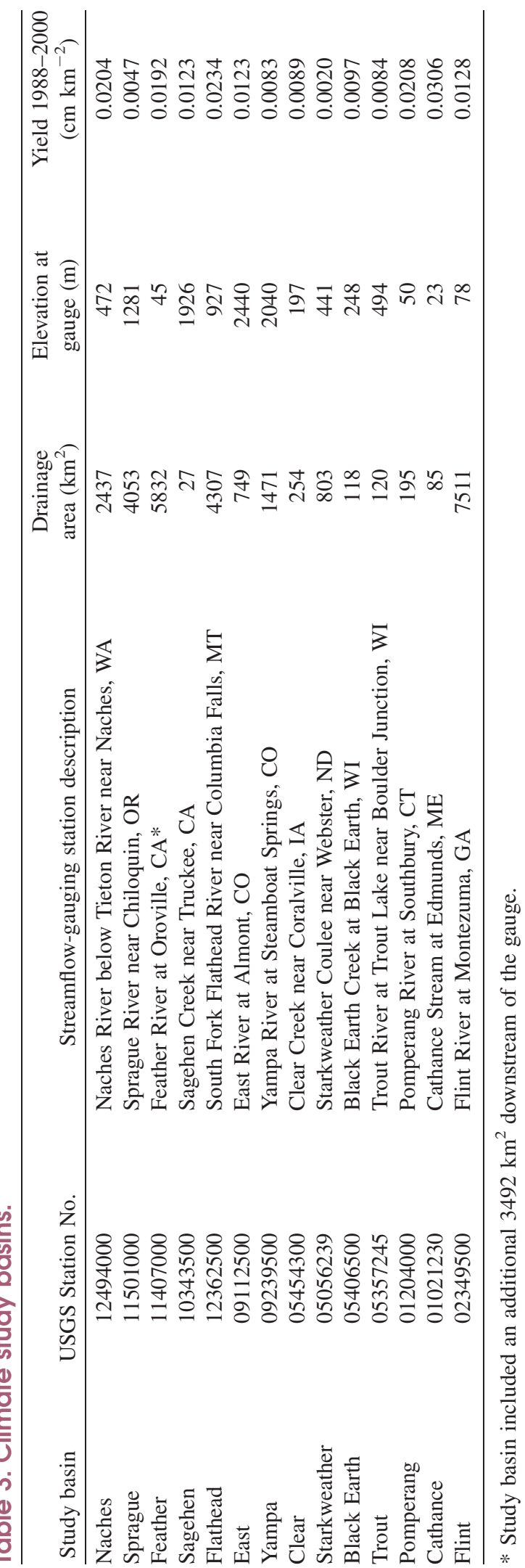


Earth Interactions - Volume 15 (2011) • Paper No. 14 • Page 8

2.2.2.2. Sagehen Creek, northern California. Sagehen Creek is a headwater tributary that flows eastward from the crest of the northern Sierra Nevada into the Truckee River before emptying into Pyramid Lake in the Great Basin. The study basin has an area of $27 \mathrm{~km}^{2}$ and ranges in elevation from 1926 to over $2600 \mathrm{~m}$ above mean sea level. Average annual precipitation ranges from approximately $850 \mathrm{~mm}$ at elevations below $2100 \mathrm{~m}$ to approximately $1200 \mathrm{~mm}$ at the basin's highest elevations. Mean annual temperature (1980-2002) at higher elevations is $3.9^{\circ} \mathrm{C}$. Although air temperature generally decreases as land surface elevation increases in most basins, in this basin temperature inversions are common. Vegetation in the basin is dominated by pine and fir forest, with grassy meadows along the main channel (Rundel et al. 1977; Andrews and Erman 1986).

\subsubsection{Rocky Mountains}

2.2.3. 1. South Fork Flathead River, western Montana. The South Fork Flathead River basin, located on the west side of the continental divide in northwestern Montana, flows into the Flathead River and ultimately into the Clark Fork of the Columbia River. With a drainage area of $4307 \mathrm{~km}^{2}$, the basin is mountainous and entirely above $900 \mathrm{~m}$ in elevation, mostly undeveloped, and forested. Almost half of the total annual precipitation is in the form of snow. Highest monthly streamflows typically occur in May as a consequence of late spring snowmelt runoff.

2.2.3.2. East River, western Colorado. Located in western Colorado, the East River basin drains into the Gunnison River basin, which is an important tributary of the Colorado River. The 749- $\mathrm{km}^{2}$ basin ranges in elevation from 2440 to $4350 \mathrm{~m}$ and has a mean elevation of $3100 \mathrm{~m}$. Most of the annual runoff occurs during April-August, with peak runoff occurring in June. Annual precipitation, over half of which is in the form of snow, is approximately $1000 \mathrm{~mm}$.

2.2.3.3. Yampa River, northwestern Colorado. The Yampa River in northwestern Colorado drains into the Green River, which is a northern tributary to the Colorado River. The study basin, whose outlet is at Steamboat Springs, has a drainage area of $1471 \mathrm{~km}^{2}$ and ranges in elevation from 2040 to $3800 \mathrm{~m}$, with a mean elevation of $2674 \mathrm{~m}$. The Yampa River basin is mountainous and the streamflow is strongly dependent on snowmelt. Most of the annual runoff occurs during April-July, with the peak runoff occurring during May or June.

\subsubsection{Midwest}

2.2.4. 1. Clear Creek, central lowa. Located in east-central Iowa, Clear Creek drains into the Iowa River and eventually into the Upper Mississippi River. The study basin has an area of $254 \mathrm{~km}^{2}$, has a general west-east orientation, and is entirely below $300 \mathrm{~m}$ in elevation. The Clear Creek basin has a wide and broad flood plain, with a meandering channel, except along reaches that have been straightened (Barnes and Eash 1990). Land use is predominantly agricultural, with a growing urban population in Johnson County, Iowa.

2.2.4.2. Starkweather Coulee, North Dakota. The Starkweather Coulee study basin in northeastern North Dakota has an area of $803 \mathrm{~km}^{2}$. Approximately onethird of the drainage area does not contribute to basin outlet streamflow because of low-relief topography. Thousands of small depressions and wetlands exist on the 
Earth Interactions - Volume 15 (2011) • Paper No. 14 • Page 9

surface. Precipitation not contributing to streamflow is lost to evapotranspiration and recharge. Soils are predominately loam to silty clay throughout the basin. Annual precipitation is approximately $500-650 \mathrm{~mm}$.

2.2.4.3. Black Earth Creek, southern Wisconsin. Located in southern Wisconsin, the groundwater-dominated Black Earth Creek flows into the Wisconsin River and eventually into the Upper Mississippi River. The study basin is $118 \mathrm{~km}^{2}$ in area and mostly flat. Mean annual precipitation is approximately $760 \mathrm{~mm}$.

2.2.4.4. Trout River, northern Wisconsin. The Trout River study basin, in northern Wisconsin, has a drainage area of $120 \mathrm{~km}^{2}$. The basin is almost entirely composed of forest and lakes. The topography is generally flat, with a total relief of less than $50 \mathrm{~m}$. The surficial geology is dominated by $30-50 \mathrm{~m}$ of unconsolidated glacial outwash overlaying Precambrian igneous bedrock. The soils are generally thin, with high organic content in the uppermost horizon (Walker and Bullen 2000).

\subsubsection{Northeast}

2.2.5. 1. Pomperang River, Connecticut. The Pomperang River study basin in Connecticut has a drainage area of $195 \mathrm{~km}^{2}$. The river flows into the Housatonic River, a tributary to the Long Island Sound. Surficial geology in the basin includes bedrock and stratified glacial deposits. Basin topographic relief ranges from 50 to over $330 \mathrm{~m}$ in elevation. Mean annual precipitation (1971-2000) is over $1250 \mathrm{~mm}$ (Daly et al. 2002).

2.2.5.2. Cathance Stream, Maine. The Cathance Stream study basin, a tributary of the Dennys River basin in eastern Maine on the Atlantic Coast, is $85 \mathrm{~km}^{2}$ in area. The basin is rural and has a rolling topography that is predominantly forested, with wetlands, lakes, ponds, and some blueberry agriculture fields. The climate is temperate, with mild summers and cold winters. Mean annual precipitation is approximately $1150 \mathrm{~mm}$ and is fairly evenly distributed throughout the year. Normal mean annual air temperature (1971-2000) is about $7.2^{\circ} \mathrm{C}$, with mean monthly air temperatures ranging from about $-7.2^{\circ} \mathrm{C}$ in January to about $19.7^{\circ} \mathrm{C}$ in July. Mean annual evapotranspiration is about $450 \mathrm{~mm}$.

\subsubsection{Southeast}

Flint River, central Georgia. The Flint River is located in western Georgia and flows from the upper Piedmont region south of Atlanta to the wetlands of the coastal plain in the southwestern corner of the state, where it flows into the Apalachicola River, which flows through the Florida Panhandle to the Gulf of Mexico. The study basin is $7511 \mathrm{~km}^{2}$ in area and encompasses the upper portion of the Flint River basin. Flows in the upper Flint River basin are unimpeded by major impoundments for almost $325 \mathrm{~km}$ and provide river habitat for a variety of fishes, mussels, and aquatic plants.

\section{Results and discussion}

Results from statistical analyses shown below include 5\%, 50\%, and 95\% streamflow exceedances; annual maximum daily streamflow; 7-day annual mean 


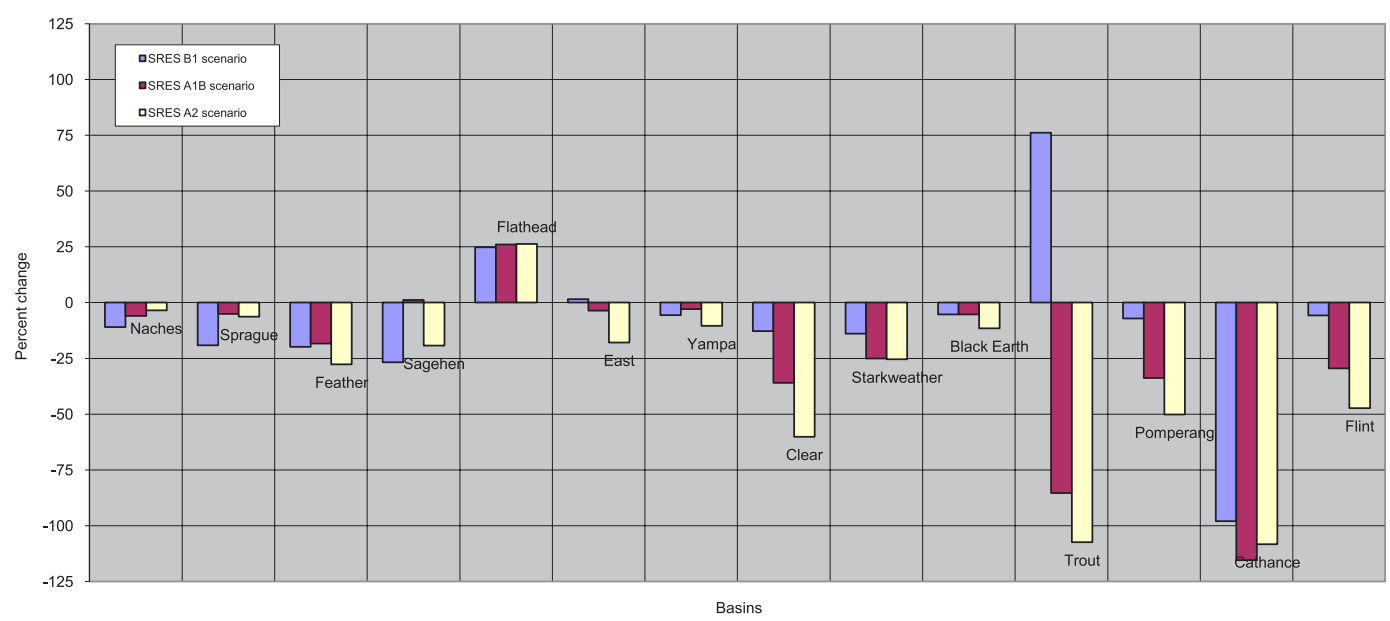

Figure 2. Percent change in regression-computed $95 \%$ streamflow exceedance between 2001-12 and 2088-99.

minimum streamflow; mean monthly streamflow; Julian date of annual maximum daily streamflow; ratios of actual evapotranspiration (AET) and potential evapotranspiration (PET) to precipitation; streamflow coefficient of variation; and streamflow probability density functions (PDFs).

\subsection{Streamflow exceedance}

Percent changes between the starting (2001-12) and ending (2088-99) periods for the $95 \%, 50 \%$, and 5\% streamflow exceedances are shown in Figures 2-4, respectively. To compute the percent change between these two periods, a regression was made based on streamflow exceedances from all eighty-eight 12-yr periods (dependent variable) and the midpoint years (2007-92) of the eighty-eight 12 -yr periods (independent variable). The regression was then used to compute the streamflow exceedance value for the starting and ending periods. These two predicted values were then used to compute the percent change shown in the plots. The reason that regression-predicted streamflow exceedances were used was to avoid having a misleading value of percent change, which could arise if either or both the starting and ending period streamflow exceedances were substantially different from the overall trend.

An indicator of low flows, the 95\% streamflow exceedance (Figure 2), decreased for almost all emission scenarios and all basins between the starting and ending periods of the twenty-first century. Significant exceptions were the Flathead River and the SRES B1 scenario for Trout River. The percent change in the medians (50\% exceedance) (Figure 3) also had a similar pattern. All basins decreased, with the exception of the Flathead and Naches basins, two of the Sprague basin scenarios, and one of the Sagehen basin scenarios. Percent changes in high flows $(5 \%$ exceedance) (Figure 4) for all basins decreased with the exception of the Sprague and Feather Rivers. 


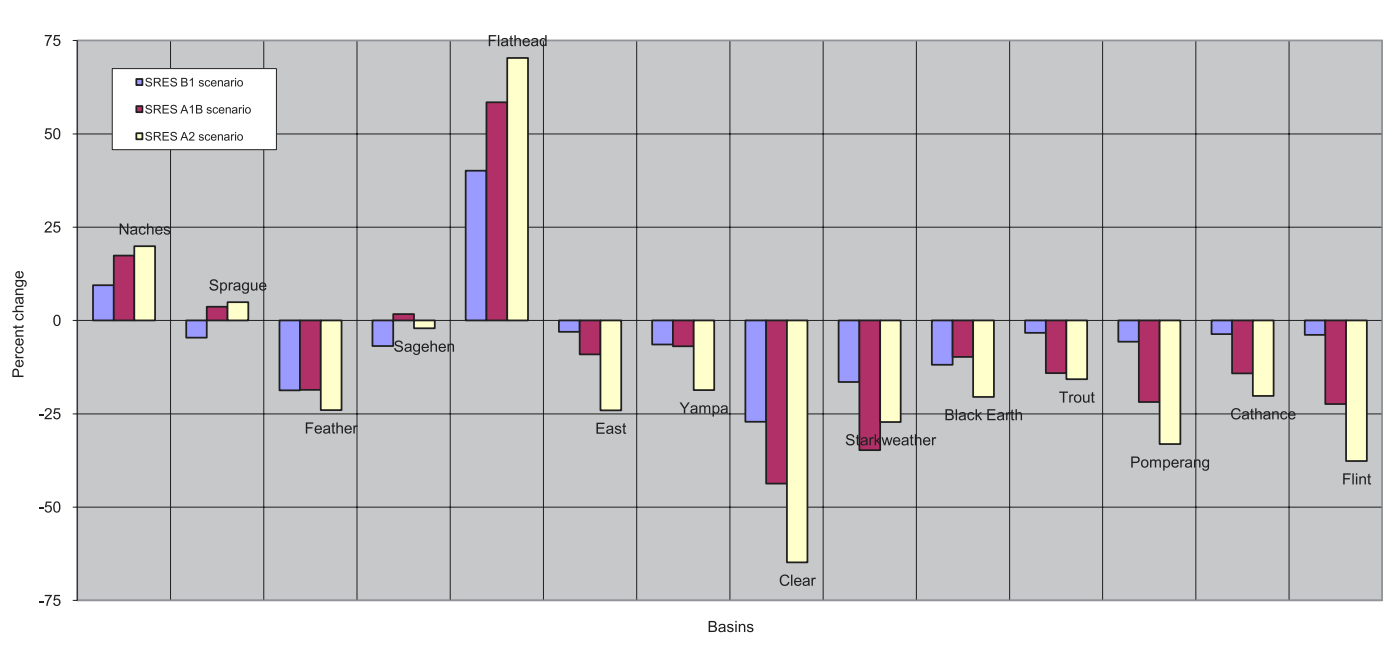

Figure 3. Percent change in regression-computed 50\% streamflow exceedance between 2001-12 and 2088-99.

The overall decrease for these streamflow exceedances was expected because all the GCMs for all emission scenarios predicted increased air temperatures, which translated into increased evapotranspiration losses in the PRMS watershed model. However, the GCMs predicted a mix of both increased and decreased precipitation depending on the basin location and the GCM. The overall decrease in streamflows for almost all the basins indicates that evapotranspiration losses were greater than gains in streamflow because of increased precipitation or were augmented by decreased precipitation.

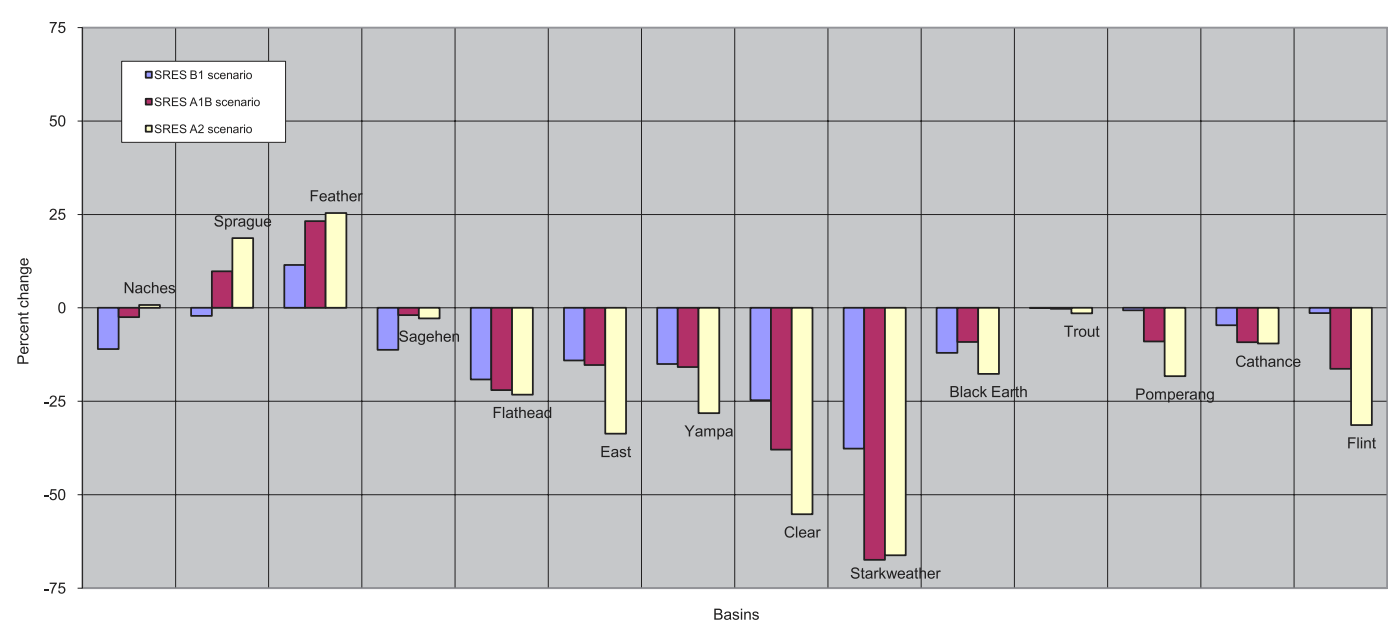

Figure 4. Percent change in regression-computed 5\% streamflow exceedance between 2001-12 and 2088-99. 


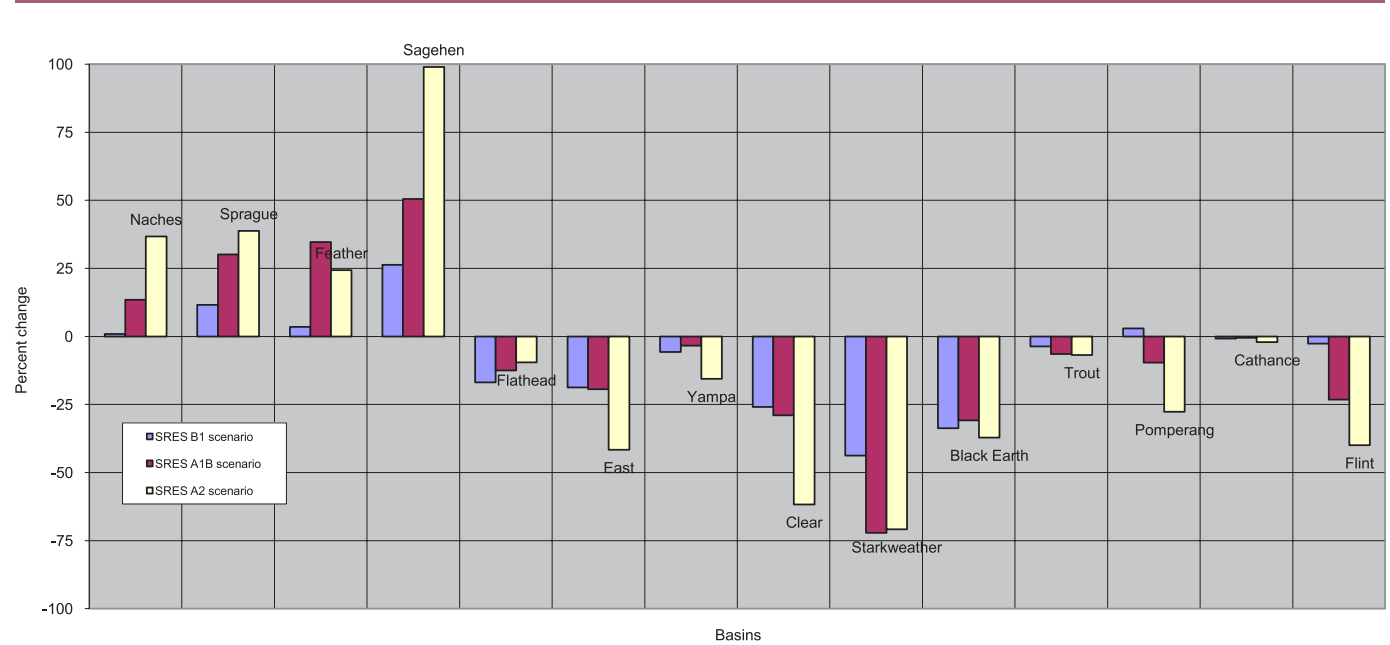

Figure 5. Percent change in regression-computed medians of annual maximum daily streamflow between 2001-12 and 2088-99.

\subsection{Annual maximum streamflow}

The percent change in the medians of annual maximum daily streamflow between the starting (2001-12) and ending (2088-99) periods decreased in the basins located in the central and eastern parts of the United States (Figure 5). Basins that increased are located in the Sierra Nevada and the Pacific Northwest. These four basins (Naches, Sprague, Feather, and Sagehen) are snowfall dominated and at elevations near the rain-snow transition. An increase in the annual maximum daily streamflow is a consequence of increased winter-rain-generated peak discharges and decreased spring-snowmelt-generated peak discharges (Knowles et al. 2006; Hay et al. 2011). With an increased proportion of winter precipitation falling as rain, peak discharges become "flashier" and have a higher magnitude. Marks and Winstral (Marks and Winstral 2007) describe differences in peak flow generation mechanisms when basins are above or below the rain-snow transition zone. Climate change can have the effect of moving the rain-snow transition zone to higher elevations, resulting in precipitation falling as rain in basins where snow historically has predominated. Because the Rocky Mountain basins (East, Yampa, and Flathead) are generally above the transition elevation zone, the precipitation still remains mostly snow even though temperatures are increasing. The percent change in annual maximum daily streamflow for those basins did not increase as it did for the far-western basins (Naches, Sprague, Feather, and Sagehen).

A comparison of lines showing the medians of the eighty-eight 12-yr period simulated annual maximum daily streamflows using the SRES A2 emission scenario for each basin is shown in Figure 6. The plotted lines for the Feather and Sagehen basins show a wet-dry cycle throughout the twenty-first century, which is an artifact of the precipitation and air temperature generated at the grid nodes by the five GCMs that were nearest to these two basins (Hay et al. 2011). Because the two basins are in close proximity to each other, the GCM climate-change deltas that were used to adjust the precipitation and air temperature input data to their 
Earth Interactions - Volume 15 (2011) • Paper No. 14 • Page 13

watershed models were identical (or nearly identical depending on the locations of the GCM grid nodes). Depending on the emissions scenario and flow statistic, basins in other regions of the country also had simulated wet-dry cycles during the twenty-first century caused by the GCMs (Hay et al. 2011). However, for the SRES A2 emissions scenario, under high-flow conditions, these cycles were most distinct in the Sierra Nevada region.

\subsection{Annual minimum streamflow}

The percent change in the 7-day mean annual minimum streamflow between the periods 2001-12 and 2088-99 decreased for all basins, with the exception of the Flathead basin in Montana and to a lesser extent the Sprague and East basins (Figure 7). As with the 95\% streamflow exceedance plots (Figure 2), low flows decreased in almost all the basins as a consequence of increased actual evapotranspiration rates that occurred in all the basins throughout the twenty-first century (Hay et al. 2011). With the exception of the Flathead basin, precipitation rates were less than actual evapotranspiration rates by the end of the century. On a percentage basis, the greatest decrease in low flow occurs in the Cathance basin in Maine. However, factors causing that decrease were unique to that basin and not regional because other eastern basins (Pomperang and Flint Rivers) did not decrease as much.

\subsection{Mean monthly streamflow}

Percent changes in mean monthly streamflow between the 2001-12 and 208899 periods decreased for all basins and for all scenarios during the summer (JuneAugust) (Table 4). In contrast, the percent changes increased in the winter for most of the basins. The impact of climate change on snowfall-dominated basins (Naches, Sprague, Feather, Sagehen, Flathead, East, Yampa, and Cathance) is evident by looking at the percent changes in mean March streamflow. For the snowfalldominated basins, spring runoff shifted to an earlier date because of warmer snowmelt conditions. For June, the high-elevation snowfall-dominated Sagehen Creek and Yampa River basins had the greatest decreases. Having more humid conditions in the summer than the arid western basins, eastern basins (Black Earth, Trout, Pomperang, Cathance, and Flint) had less pronounced decreases in the mean June streamflow.

\subsection{Annual maximum streamflow date}

Another indicator of changes in snowfall-dominated spring runoff is the change in the Julian date of the annual maximum daily streamflow (Figure 8). Although Julian dates decreased for all basins and all scenarios with exception of the Flint basin SRES A1B scenario, the western snowfall-dominated basins had the greatest decreases. For the eastern basins, Cathance Stream basin also had a significant decrease. The Naches River basin showed the greatest percent decrease as the date of maximum streamflow shifted from late April to late January, which is indicative of a change in the flood generation mechanism from a spring-snowmelt-dominated stream to a winter-rainfall-dominated stream (Figure 9). 


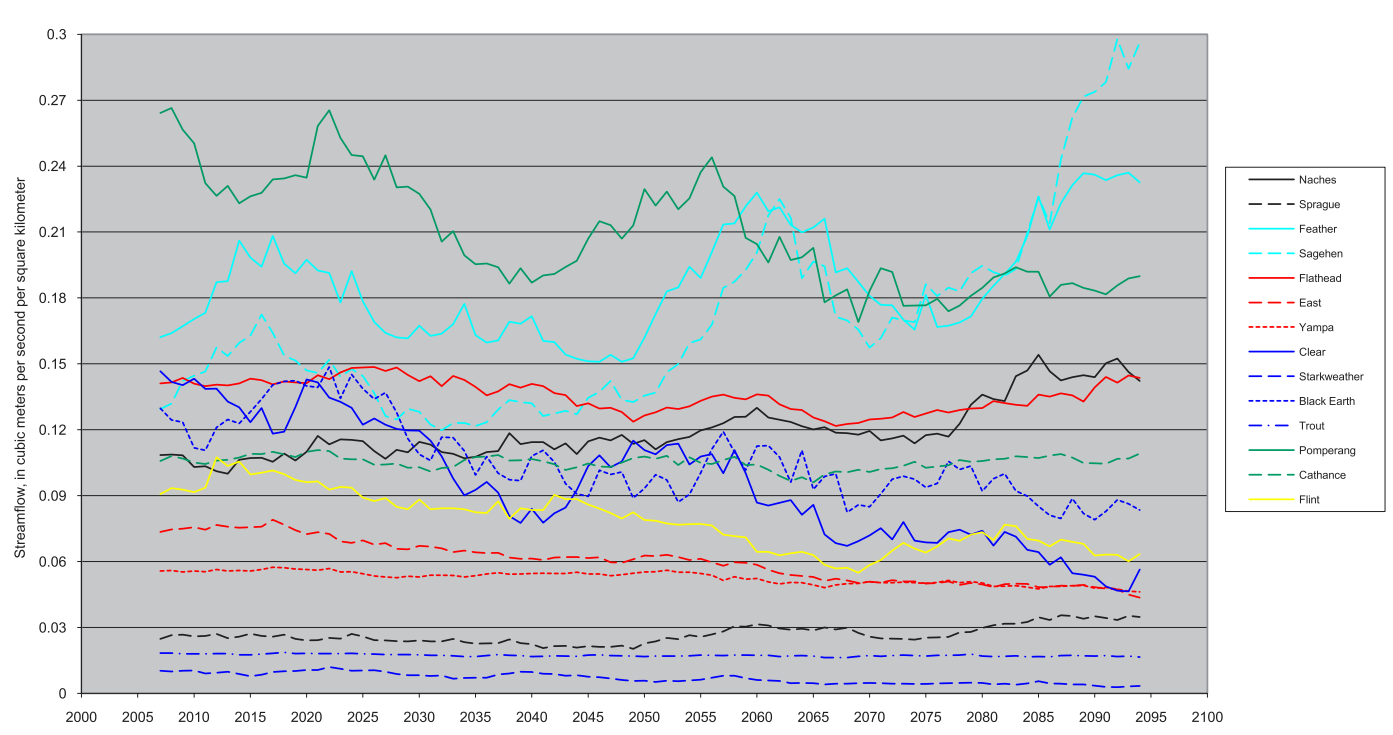

Figure 6. Median of annual maximum daily streamflow of the eighty-eight 12-yr SRES A2 scenario simulations normalized by drainage area.

\subsection{Water and energy supply}

Milly and Dunne (Milly and Dunne 2002) and Clark et al. (Clark et al. 2008) discuss varying controls on the supply of available energy and available water in a basin by partitioning precipitation between evaporation and runoff. These controls can be seen in a relation between an index of dryness pet $/ p$ and an evaporation ratio $e / p$, where pet is potential evapotranspiration, $p$ is precipitation, and $e$ is evaporation. For basins that have an index of dryness of $<1.0$, annual evaporation is

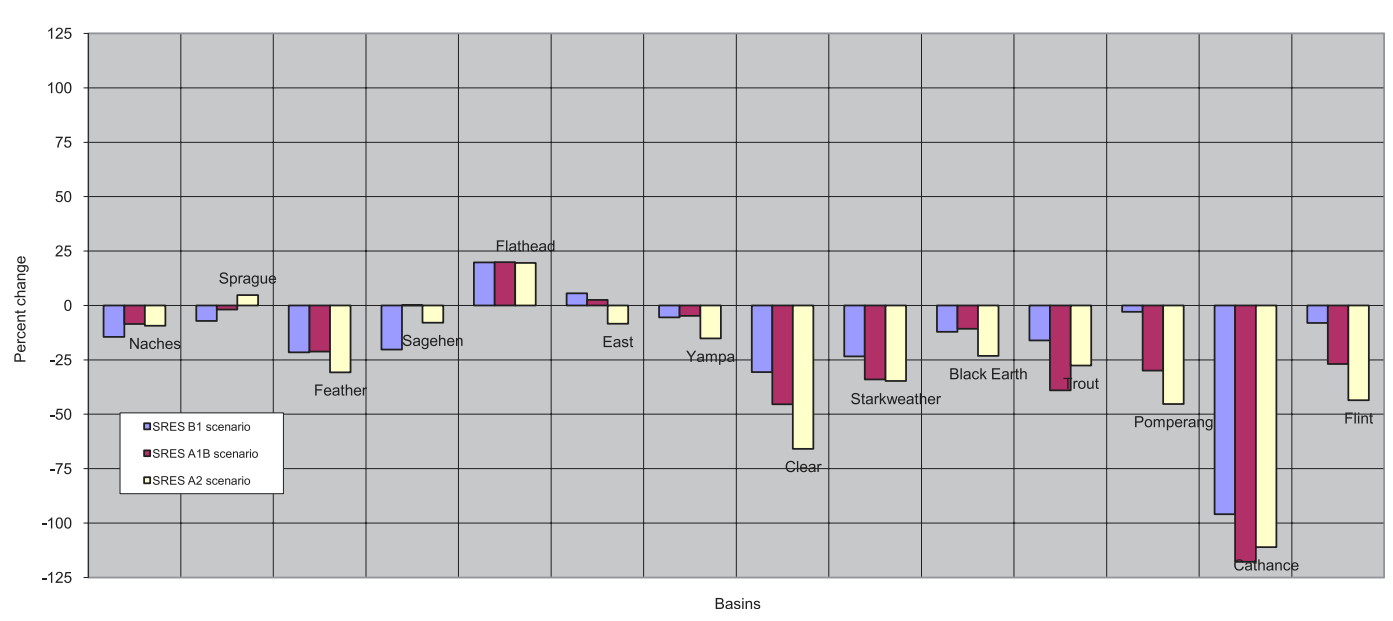

Figure 7. Percent change in regression-computed medians of 7-day mean annual minimum streamflow between 2001-12 and 2088-99. 
Earth Interactions - Volume 15 (2011) • Paper No. 14 • Page 15

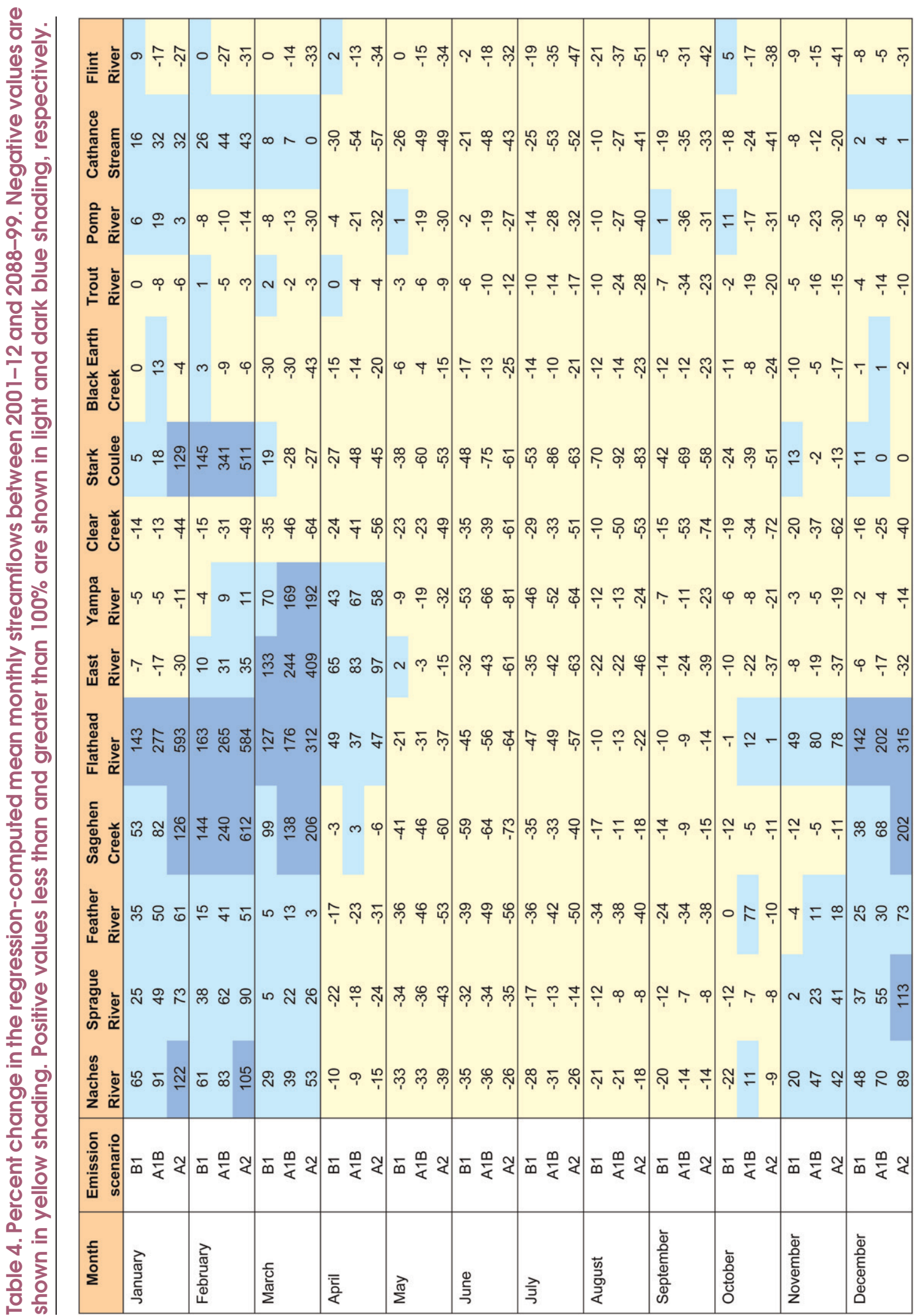


Earth Interactions - Volume 15 (2011) • Paper No. 14 • Page 16

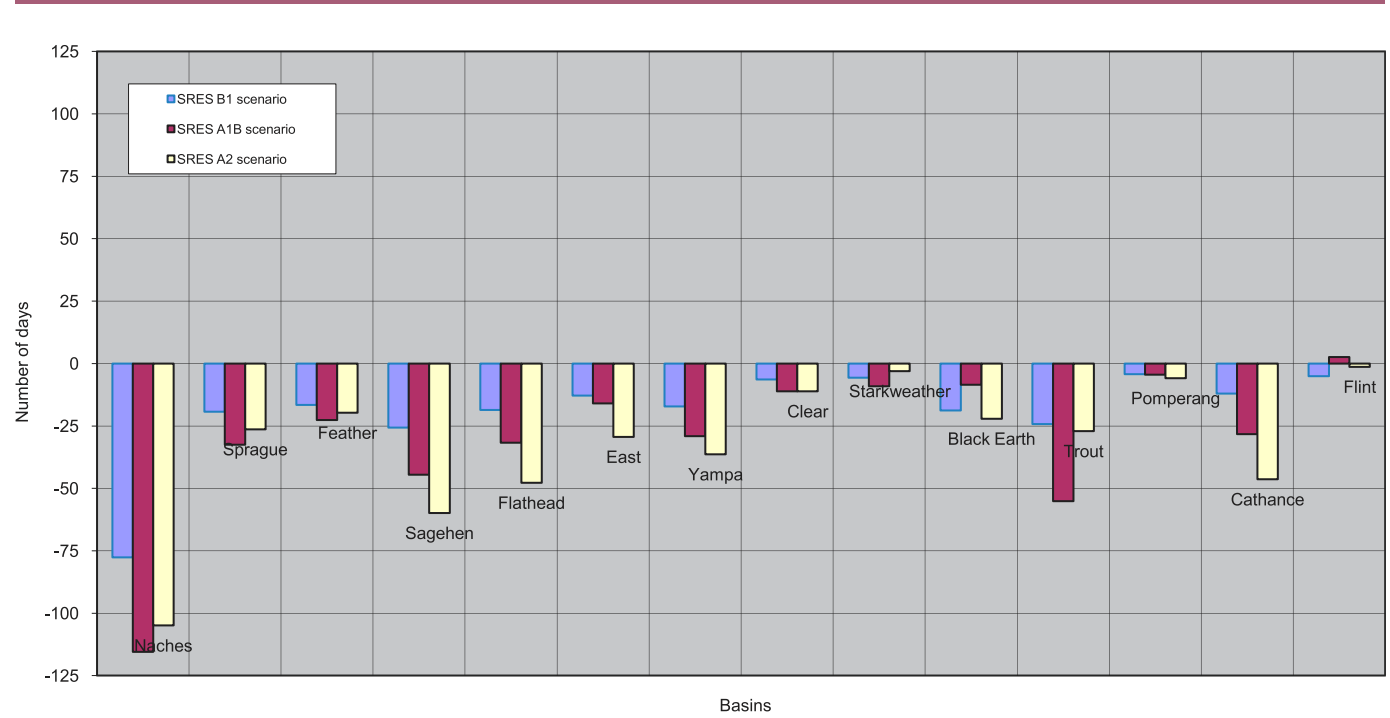

Figure 8. Percent change in regression-computed medians of the Julian date of the annual maximum daily streamflow between 2001-12 and 2088-99.

constrained by the annual supply of energy. Conversely, for basins that have an index of dryness equal to 1.0 or greater, annual evaporation is constrained by the annual supply of water. For large river basins (10 $000 \mathrm{~km}^{2}$ and greater), these controls can be predicted by the Turc-Pike relation, given by Milly and Dunne (Milly and Dunne 2002) as

$$
e / p=\left[1+(\text { pet } / p)^{-v}\right]^{-1 / v}
$$

where $v=2$.

Using simulated daily actual evapotranspiration, daily potential evapotranspiration, and daily precipitation output from the SRES A2 scenario runs for the 2001-12 and 2088-99 periods from the 14 PRMS/GSFLOW watershed models, index of dryness and evaporation ratios were computed (Figure 10). For consistency, all the watershed models used the Jensen-Haise method of computing potential evapotranspiration. This method overestimated potential evapotranspiration in some of the basins because values for the index of dryness ( $x$ axis of the plot) theoretically should be less than 1.0. However, for the objective of this analysis, all model parameter values were consistent and unchanged between the 2001-12 and 2088-99 period simulations. Of interest, then, are the plotting positions of the basins in relation to each other and the impact of climate change on the relation between the index of dryness pet $/ p$ and the evaporation ratio $e / p$ for each basin. The index of dryness ( $x$ axis) for all 14 basins increased (Table 5). Basins with the largest increases in their dryness index were Flint, Clear, East, Yampa, and Starkweather. These increases are essentially a reflection of specific GCM air temperature predictions for those locations because the Jensen-Haise routine in PRMS computes potential evapotranspiration as a function of air temperature. 


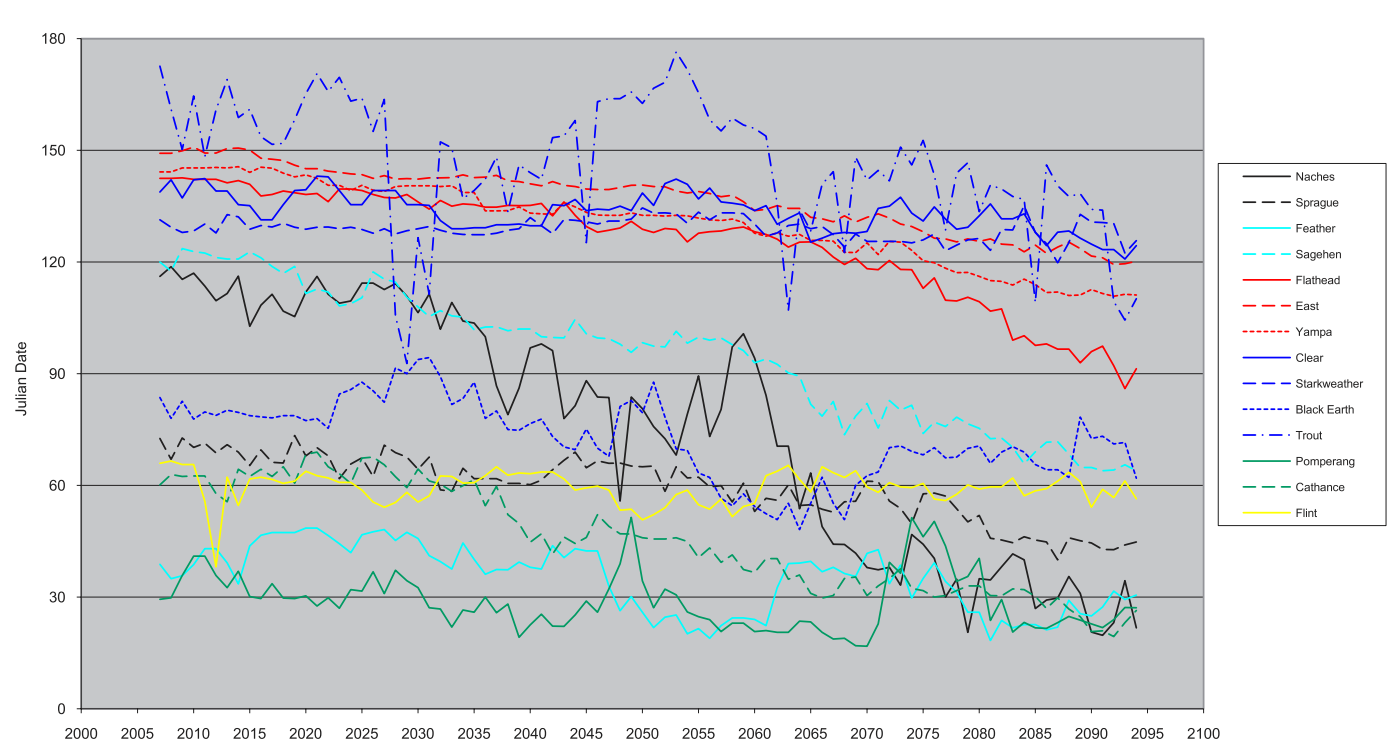

Figure 9. Medians of the Julian dates of the annual maximum daily streamflow for the eighty-eight 12-yr SRES A2 scenario simulations.

Most of the evaporation ratios ( $y$ axis) also increased. However, there was a slight decrease in the evaporation ratio for the four far-western basins (Naches, Sprague, Feather, and Sagehen), which have snow-dominated runoff processes. Because they are geographically in proximity with each other, they were also subject to a similar Pacific Ocean maritime-influenced climate of wet winters and hot, dry summers. Increasing air temperatures and decreased snowpack storage would create drier soil-moisture conditions in the summer. Actual evapotranspiration would then be limited by water supply in the summer, which would decrease the evaporation ratio even if total annual precipitation was unchanged.

\subsection{Variability}

Two measures of the impact of climate change on streamflow variability in the 14 basins include the coefficient of variation (standard deviation divided by mean) and PDFs.

\subsubsection{Coefficient of variation}

The coefficient of variation was computed from simulated daily streamflow for each basin for each of the eighty-eight 12-yr periods. For most of the basins, the coefficient of variation increased (Figure 11). The coefficient of variation decreased for the Flathead, East, and Black Earth basins. These changes are also seen in the coefficient of variation of the SRES A2 scenario simulations alone over the twenty-first century (Figure 12). In this plot, the magnitudes of coefficient of variation for each basin are compared with each other. The Starkweather, Sagehen, and Clear basins had the highest coefficients $(>2.5)$. Most other basins had 
Earth Interactions - Volume 15 (2011) • Paper No. 14 • Page 18

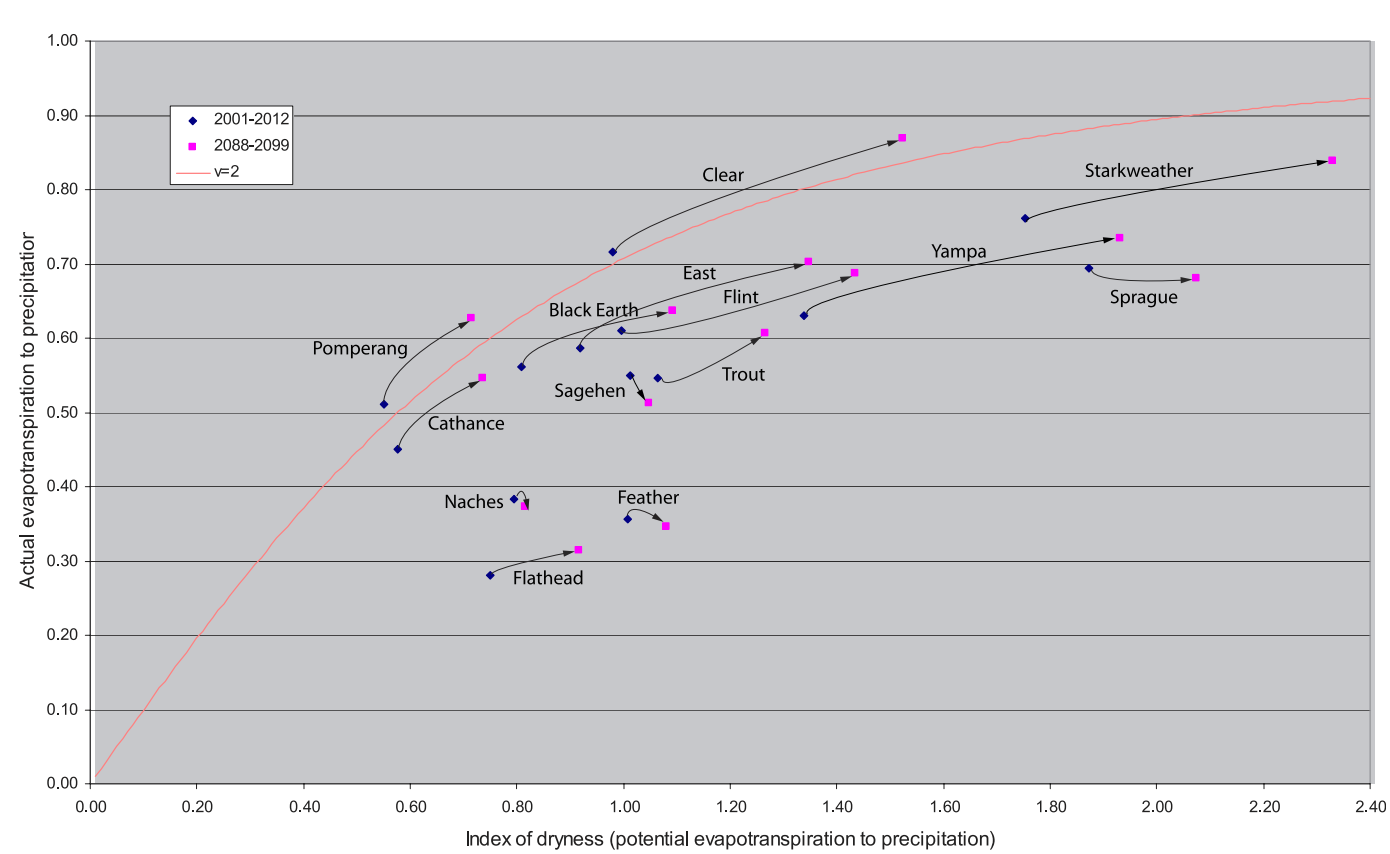

Figure 10. Change in the ratios of AET and PET to precipitation between 2001-12 and 2088-99 SRES A2 scenario simulations.

coefficients that were $<2.0$ for all 88 of the 12 -yr periods. For the Starkweather and Clear basins, high variability might be indicative of runoff conditions in the upper Midwest. However, the high variability of the Sagehen basin is most likely explained by its small drainage area. With only $27 \mathrm{~km}^{2}$, this basin is the smallest of

Table 5. Percent change in AET and PET to precipitation ratios between the 2001-12 and 2088-99 simulations.

\begin{tabular}{lcc}
\hline \multicolumn{1}{c}{ Stream location } & $\begin{array}{c}\text { PET/PPT } \\
x \text { axis } \\
\text { percent change }\end{array}$ & $\begin{array}{c}\text { AET/PPT } \\
\text { axis } \\
\text { percent change }\end{array}$ \\
\hline Naches River below Tieton River near Naches, WA & 3 & -3 \\
Sprague River near Chiloquin, OR & 11 & -2 \\
Feather River at Oroville, CA & 7 & -3 \\
Sagehen Creek near Truckee, CA & 4 & -7 \\
South Fork Flathead River near Columbia Falls, MT & 22 & 12 \\
East River at Almont, CO & 47 & 20 \\
Yampa River at Steamboat Springs, CO & 44 & 17 \\
Clear Creek near Coralville, IA & 55 & 22 \\
Starkweather Coulee near Webster, ND & 33 & 10 \\
Black Earth Creek at Black Earth, WI & 35 & 13 \\
Trout River at Trout Lake near Boulder Junction, WI & 19 & 11 \\
Pomperang River at Southbury, CT & 30 & 23 \\
Cathance Stream at Edmunds, ME & 28 & 21 \\
Flint River at Montezuma, GA & 44 & 13 \\
\hline
\end{tabular}




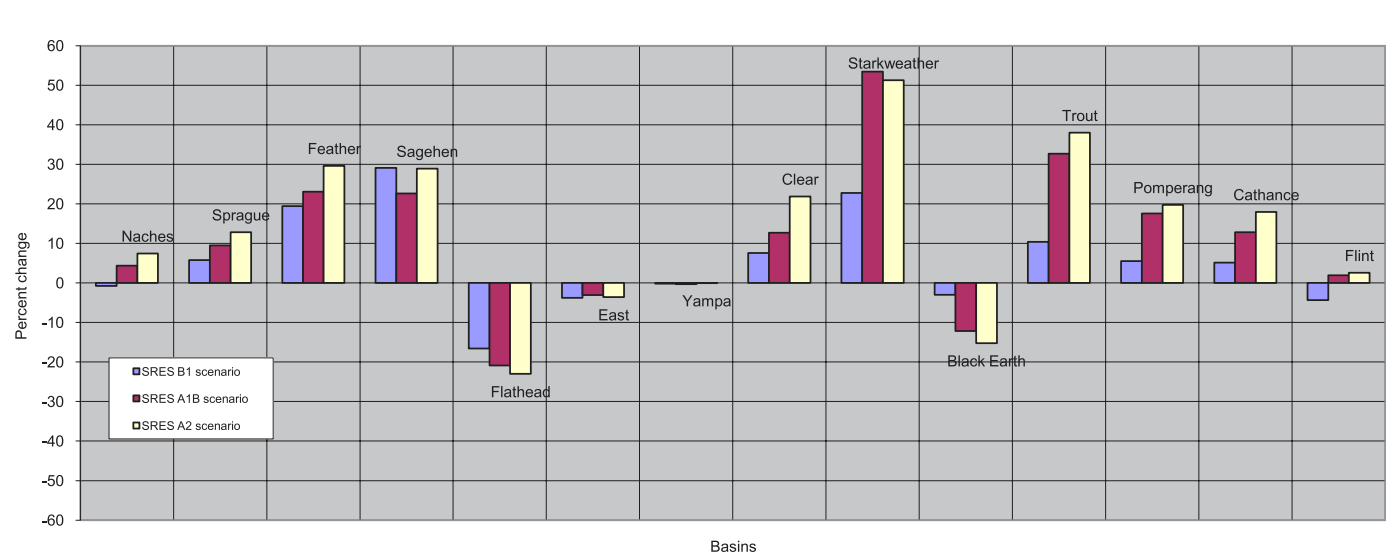

Figure 11. Percent change in regression-computed coefficients of variation of daily streamflow between 2001-12 and 2088-99.

the 14 study basins. Having limited storage capacity, streamflow in a small basin is often "flashier" and can more dramatically vary from one year to another.

\subsubsection{Probability distributions of annual streamflows}

Probability density functions were created for each basin based on mean annual streamflows. Each PDF was created using 180 values (12 years of mean annual streamflow $\times 5$ models $\times 3$ emission scenarios) (Figure 13). Eight 12-yr periods shown in the plots include the following: 2001-12, 2013-24, 2025-36, 2037-48,

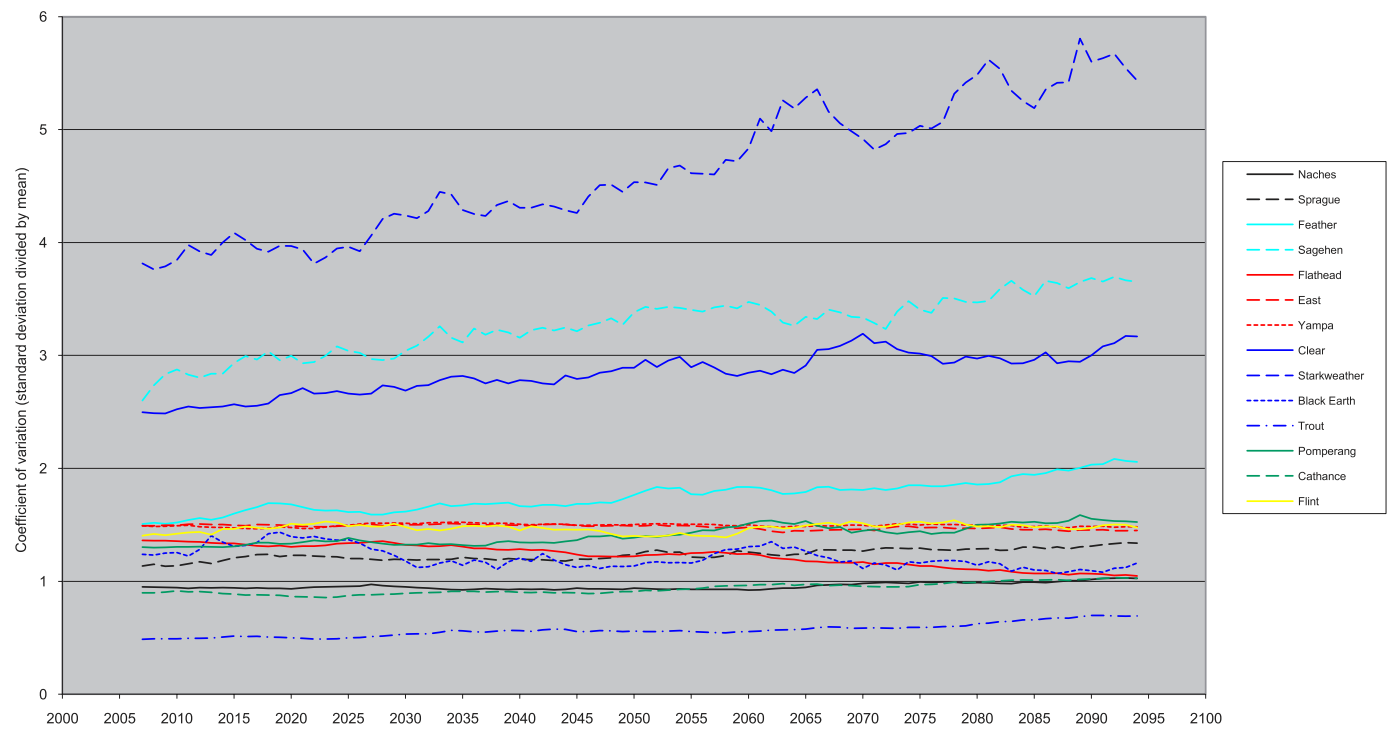

Figure 12. Coefficients of variation of daily streamflow of the eighty-eight 12-yr SRES A2 scenario simulations. 
Earth Interactions - Volume 15 (2011) • Paper No. 14 • Page 20
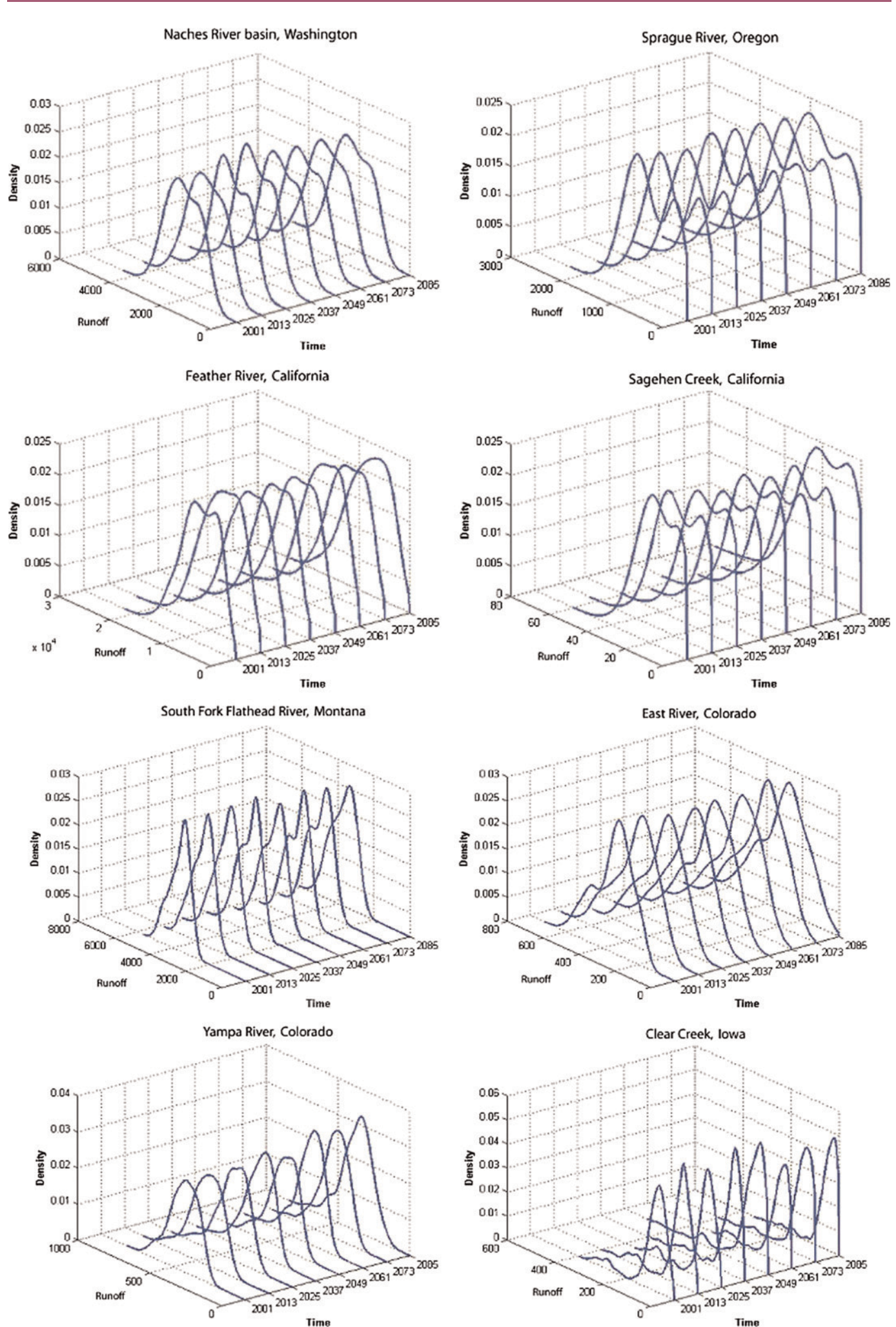

Figure 13. Three-dimensional probability density curves for each basin of mean annual simulated streamflow from five models and three emission scenarios for 2001-12, 2013-24, 2025-36, 2037-48, 2049-60, 2061-72, 207384 , and 2085-96. 

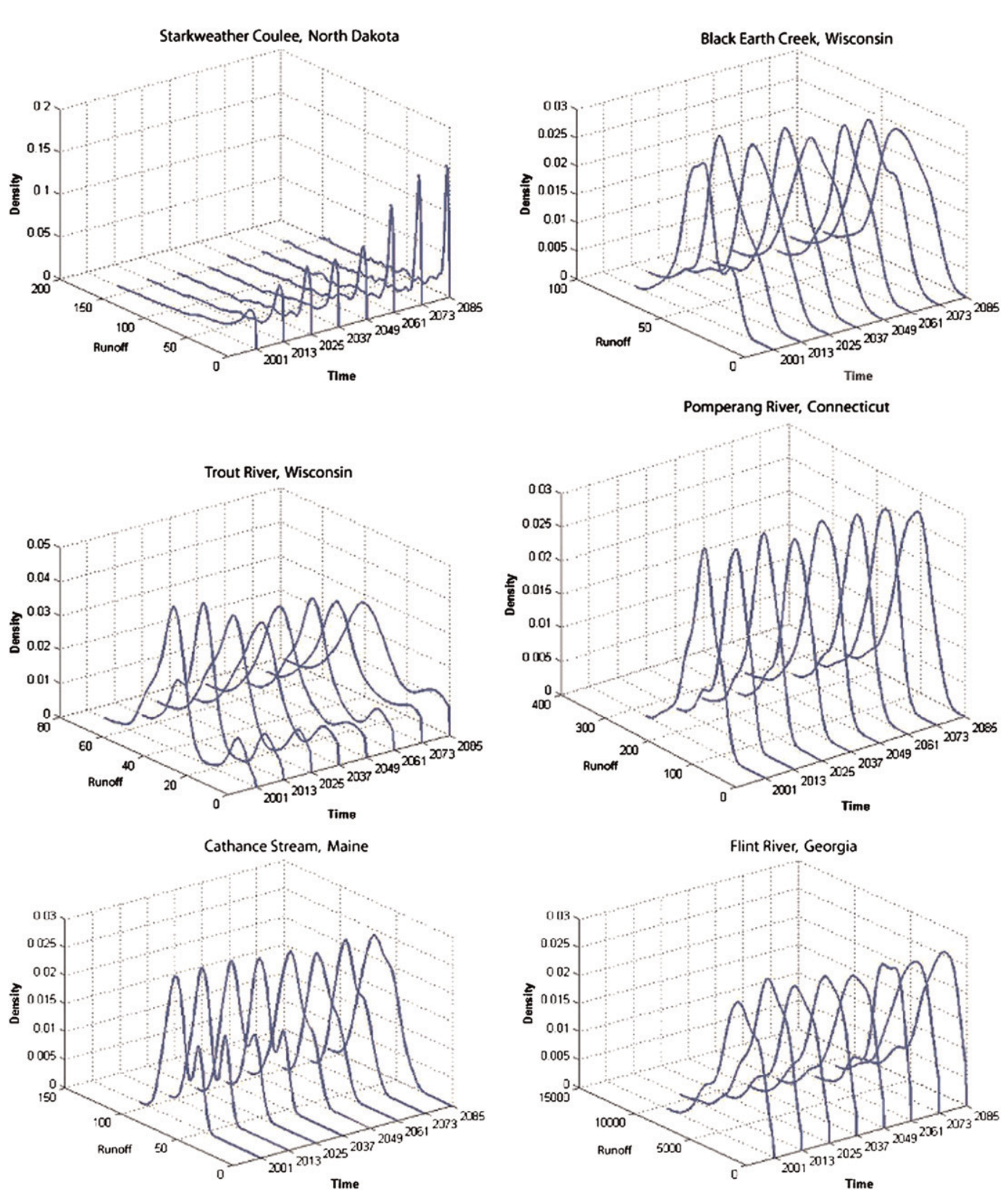

Figure 13. (Continued)

2049-60, 2061-72, 2073-84, and 2085-96. Similar to the coefficient of variation plots, the Starkweather and Clear basin PDFs also are highly dispersed and skewed (positive). In the other extreme, the Flathead, Pomperang, and Cathance basin PDFs have less dispersion than most basin PDFs. Four basin PDFs sets (Naches, Sprague, Sagehen, Trout, and Cathance basins) were bimodal. KolmogorovSmirnov tests on the PDFs determined that almost all the basin distributions were nonparametric. The nonnormality of the PDFs is an artifact of the current condition 
Earth Interactions - Volume 15 (2011) • Paper No. 14 • Page 22

Table 6. Kolmogorov-Smirnov test of differences between 2001-12 and 2085-96 simulated mean annual streamflows of the five models and three emission scenarios.

\begin{tabular}{lcc}
\hline \multicolumn{1}{c}{ Stream location } & D statistic & $p$ value \\
\hline Naches River below Tieton River near Naches, WA & 0.1167 & 0.16 \\
Sprague River near Chiloquin, OR & 0.1111 & 0.20 \\
Feather River at Oroville, CA & 0.1389 & 0.06 \\
Sagehen Creek near Truckee, CA & 0.1607 & 0.02 \\
South Fork Flathead River near Columbia Falls, MT & 0.0889 & 0.46 \\
East River at Almont, CO & 0.2000 & 0.00 \\
Yampa River at Steamboat Springs, CO & 0.3111 & 0.00 \\
Clear Creek near Coralville, IA & 0.4056 & 0.00 \\
Starkweather Coulee near Webster, ND & 0.2778 & 0.00 \\
Black Earth Creek at Black Earth, WI & 0.2722 & 0.00 \\
Trout River at Trout Lake near Boulder Junction, WI & 0.2389 & 0.00 \\
Pomperang River at Southbury, CT & 0.3111 & 0.00 \\
Cathance Stream at Edmunds, ME & 0.2778 & 0.00 \\
Flint River at Montezuma, GA & 0.2167 & 0.00 \\
\hline
\end{tabular}

period (1988-99) daily precipitation and air temperature records for the basins and the monthly GCM precipitation and air temperature output. Perhaps more important are changes seen in the PDF curves over the twenty-first century (Figure 13). The Yampa and Starkweather basins PDF curves increase in height and sharpen. However, the Trout basin PDF curve dampens over time. With exception of 4 basins (Naches, Sprague, Feather, and Flathead), which are all located in the western United States and snow dominated, Kolmogorov-Smirnov tests showed a significant difference between the beginning (2001-12) and ending (2085-96) PDFs for the other 10 basins (Table 6). From the Kolmogorov-Smirnov results, it could be inferred that, for the far-western snow-dominated basins, climate change does not alter mean annual streamflow. However, as discussed earlier, it does alter the monthly distribution of streamflow. For other locations, such as the Midwest, Northeast, and Southeast, climate change significantly alters mean annual streamflow and, as discussed earlier, the proportions of evapotranspiration and precipitation of the basin water budget.

\subsection{Uncertainty assessment}

Three major sources of uncertainty in the modeling process in this study are the GCMs, the downscaling techniques, and the watershed model. GCMs are limited in their representation of Earth's physical processes, model resolution, and linkages between the atmosphere, ocean, and land bodies. For the five GCMs used in this study, the latitude and longitude grid spacing of the atmospheric component ranged from $1.9^{\circ}$ to $4.0^{\circ}$ and from $1.9^{\circ}$ to $5.0^{\circ}$, respectively (Alley 2007). For the study basin latitudes, a $5^{\circ}$ distance between longitudes ranges from approximately 350 to $450 \mathrm{~km}$, which is a climate input grid spacing that is too coarse for many watershed modeling applications. The emission scenarios used to drive the GCMs also adds uncertainty because they are based on an array of future political, social, economic, and technological factors. For that reason, three different future emission scenarios were used in this study as a means of widening the range of possible outcomes. 
In the downscaling method used in this study, spatial interpolations were not made to the GCM-generated precipitation and air temperature data for individual basins based on their location between the GCM grid nodes. Climate input data for each watershed model was derived from the closest grid node to the basin. As a consequence, elevation and possible orographic differences between the basin and the grid node introduced additional uncertainty to the modeling process. Temporal downscaling in the study was based on simple monthly adjustments of 1988-2000 period daily precipitation and air temperature records. With this method, it was assumed that the daily timing and duration of future climate events remained unchanged because only the magnitude of daily climate data changed. Although these downscaling methods are simple, Fowler et al. (Fowler et al. 2007) concluded that more sophisticated downscaling methods do not necessarily reduce uncertainty.

Additional sources of uncertainty in the modeling process were associated with the hydrologic model. The current practice in hydrologic modeling is to rely on a single model to conduct the simulation of land surface fluxes/states. Despite the considerable progress made in developing various hydrologic models, there is no conceivable reason that any particular model in existence is superior to other models across the spatial and temporal domains for various applications and under all circumstances (Hsu et al. 2009; Raftery et al. 2005). This results in reducing the size of the plausible model space and often leads to predictions that may well represent some phenomena or events at the expense of others. In addition, assessment of predictive uncertainty, based on a single model, is subject to statistical bias and the structural error inherent in any single model. Like all watershed models, PRMS output contains error in the data, parameterization, and model structure. Data measurement error exists in the air temperature and precipitation model input data and the streamflow model calibration data. $\mathrm{Pa}$ rameterization error is a function of how well the models were calibrated and verified. Structural error is related to how well the watershed model represents the physical, water, and energy processes in the basin. Hay et al. (Hay et al. 2011) provide an extensive discussion on uncertainty associated with the PRMS method of simulating potential evapotranspiration. PRMS uses an empirically based algorithm to simulate PET with air temperature and precipitation as input. Another source of model uncertainty is the lack of feedback mechanisms between PRMS and climate change. PRMS was calibrated for 1988-2000 land surface conditions. Present-day runoff processes were assumed to remain constant throughout the twenty-first century. A more ideal watershed model would include dynamic land surface parameters that are adjusted in the future as the ecosystem is altered by climate change.

With numerous sources of uncertainty in the modeling stages of this study, it can be acknowledged that, for any one of the 14 study basins, the simulated hydrologic change resulting from climate change could be within the upper and lower bounds of the cumulated uncertainty. However, a major strength and uniqueness of this study is the application of a national and consistent modeling approach on a variety of ecologically and climatically diverse basin sites. It is then possible to compare and assess the relative impacts of climate change on hydrology between regions rather than attempting to predict the hydrologic outcome of a single given basin. 
Earth Interactions - Volume 15 (2011) • Paper No. 14 • Page 24

\section{Summary}

Streamflow statistics for 14 selected basins across the United States that were developed from output from an earlier climate-change modeling study were compared. Ranging in size from 27 to $9324 \mathrm{~km}^{2}$, the basins included two in the Sierra Nevada, two in the Pacific Northwest, four in the Rocky Mountains, three in the upper Midwest, two in New England, and one in the Southeast. For the earlier climate-change study, sets of simulated air temperature and precipitation data for the entire twenty-first century and for three emission scenarios of possible future carbon loading levels were assembled from five general circulation models. After downscaling, the climate data were used as input to a precalibrated precipitation-runoff model for each of the 14 basins. Simulated daily streamflow and energy output from the watershed models were used to compute statistics, which included 5\%,50\%, and 95\% streamflow exceedance; annual maximum daily streamflow; 7-day mean annual minimum streamflow; mean monthly streamflow; Julian date of annual maximum daily streamflow; ratios of actual and potential evapotranspiration to precipitation; streamflow coefficient of variation; and streamflow probability density curves.

With the exception of the Flathead River basin in Montana, the low-flow 95\% streamflow exceedance decreased for all basins for almost all emission scenarios between the beginning and end of the twenty-first century. For the 50\% streamflow exceedance, all basins decreased for most of the scenarios, except for the Flathead and Naches basins. However, for the high-flow 5\% streamflow exceedance, all basins decreased for most of the scenarios except for the Sprague and Feather basins. Annual maximum daily streamflow decreased in all the basins located in the Rocky Mountains, the Midwest, and eastern parts of the United States. However, the annual maximum daily streamflow increased in the four basins located in the far west (California and the Pacific Northwest), which is attributed to a change in the peak flow generation mechanism from less spring snowmelt to more winter rainfall. The 7-day mean annual minimum daily streamflow decreased for all basins in most scenarios with the exception of the Flathead and East basins. The Cathance basin in Maine had the greatest low-flow decrease. For the summer (June-August), mean monthly streamflow decreased entirely for all 14 basins and for all emission scenarios. In contrast, monthly streamflow increased in the winter for most but not all of the basins. As an indicator of changes in snowmelt runoff processes, the Julian date of annual maximum daily streamflow decreased for all basins and for all emission scenarios with the exception of SRES A1B scenario of the Flint basin in Georgia. The Naches River basin showed the greatest change as its date of maximum streamflow shifted from late April to late January.

Using simulated daily output from the 14 watershed models, "index of dryness" (potential evapotranspiration/precipitation) and evaporation/precipitation ratios for the beginning and ending simulations periods of the twenty-first century were computed. The relation between these two ratios is a representation of the controls on the supply of available energy and available water for a basin. For this analysis, the index of dryness increased for all the basins. The evaporation/precipitation ratio also increased for most basins, except the four basins in California and the Pacific Northwest, which have similar snowmelt runoff processes and are in geographic proximity to similar Pacific Ocean-influenced climate conditions.

Probability density functions based on simulated annual streamflows from all the GCM models and emission scenarios were created for each basin and used 
to assess the impact of climate change on annual streamflow variability throughout the twenty-first century. PDFs for two basins in the upper Midwest (Starkweather and Clear) were more dispersed and skewed than the other basins. Kolmogorov-Smirnov tests showed a significant difference between the beginning (2001-12) and ending (2085-96) PDFs for 10 basins. The remaining four basins without significant differences are located in the far-western United States and are snow dominated.

Finally, results presented in this paper must be considered within the context of modeling uncertainty. Major sources of uncertainty in this study include the GCMs, the downscaling techniques, and the watershed model. It is acknowledged that, for any of the 14 study basins, the simulated hydrologic differences resulting from climate change could be within the upper and lower bounds of the uncertainty that is accumulated in the modeling steps. This should be expected with any assessment of climate change impacts on streamflows that is based on downscaled climate data and a basin-scaled hydrologic model. The uniqueness of this study was the application of a consistent modeling approach over most of the continental United States using basin locations representing diverse landscapes. With this approach, the relative impacts of climate change on hydrology between different ecological and climatic regions could then be compared and assessed.

Acknowledgments. This work was supported by the U.S. Geological Survey through the Global Change Research and Development Program. Adam Stonewall and Mark Mastin provided thoughtful reviews that improved this manuscript.

\section{References}

Alley, R. B., 2007: Summary for policymakers. Climate Change 2007: The Physical Science Basis, S. Solomon et al., Eds., Cambridge University Press, 1-18.

Andrews, E. D., and D. C. Erman, 1986: Persistence in the size distribution of surficial bed material during an extreme snowmelt flood. Water Resour. Res., 22, 191-197.

Barnes, K. K., and D. A. Eash, 1990: Flood of June 17, 1990, in the Clear Creek basin, east-central Iowa. U.S. Geological Survey Open-File Rep. 94-78, 16 pp.

Bernstein, L., and Coauthors, 2007: Climate Change 2007: Synthesis Report. Cambridge University Press, 104 pp.

Chang, H., and I. W. Jung, 2010: Spatial and temporal changes in runoff caused by climate change in a complex large river basin in Oregon. J. Hydrol., 388, 186-207.

Clark, M. P., A. G. Slater, D. E. Rupp, R. A. Woods, J. A. Vrugt, H. V. Gupta, T. Wagener, and L. E. Hay, 2008: Framework for Understanding Structural Errors (FUSE): A modular framework to diagnose differences between hydrological models. Water Resour. Res., 44, W00B02, doi:10.1029/2007WR006735.

Dagnachew, L., V. C. Christine, and G. Francoise, 2003: Hydrological response of a catchment to climate and land use changes in tropical Africa: Case study south central Ethiopia. J. Hydrol., 275, 67-85.

Daly, C., W. P. Gibson, G. H. Taylor, G. L. Johnson, and P. Pasteris, 2002: A knowledge-based approach to the statistical mapping of climate. Climate Res., 22, 99-113.

Dibike, Y., and P. Coulibaly, 2005: Hydrologic impact of climate change in the Saguenay watershed: Comparison of downscaling methods and hydrologic models. J. Hydrol., 307, 145-163.

Fowler, H. J., S. Blenkinsopa, and C. Tebaldi, 2007: Linking climate change modelling to impacts studies: Recent advances in downscaling techniques for hydrological modeling. Int. J. Climatol., 27, 1547-1578.

Hamlet, A., and D. Lettenmaier, 1999: Effects of climate change on hydrology and water resources in the Columbia River basin. J. Amer. Water Resour. Assoc., 35, 1597-1623. 


\section{Earth Interactions - Volume 15 (2011) • Paper No. 14 • Page 26}

Hay, L. E., S. L. Markstrom, and C. Ward-Garrison, 2011: Watershed-scale response to climate change through the twenty-first century for selected basins across the United States. Earth Interact., 15. [Available online at http://EarthInteractions.org.]

Hsu, K., H. Moradkhani, and S. Sorooshian, 2009: A sequential Bayesian approach for hydrologic model selection and prediction. Water Resour. Res., 45, W00B12, doi:10.1029/2008WR006824.

Knowles, N., M. D. Dettinger, and D. R. Cayan, 2006: Trends in snowfall versus rainfall in the western United States. J. Climate, 19, 4545-4559.

Leavesley, G. H., M. D. Branson, and L. E. Hay, 1992: Using coupled atmospheric and hydrologic models to investigate the effects of climate change in mountainous regions. Managing Water Resources during Global Change, R. Herrmann, Ed., 691-700.

Leung, L. R., and M. Wigmosta, 1999: Potential climate change impacts on mountain watersheds in the Pacific Northwest. J. Amer. Water Resour. Assoc., 35, 1463-1471.

Marks, D. G., and A. H. Winstral, 2007: Finding the rain/snow transition elevation during storm events in mountain basins. Proc. Joint Symp. JHW001: Interactions between Snow, Vegetation and the Atmosphere, Perugia, Italy, IUGG.

Markstrom, S. L., R. G. Niswonger, R. S. Regan, D. E. Prudic, and P. M. Barlow, 2008: GSFLOW-Coupled ground-water and surface-water flow model based on the integration of the Precipitation-Runoff Modeling System (PRMS) and the Modular Ground-Water Flow Model (MODFLOW-2005). U.S. Geological Survey Techniques and Methods 6-D1, 240 pp.

Milly, P. C. D., and K. A. Dunne, 2002: Macroscale water fluxes, 2. Water and energy supply control of their interannual variability. Water Resour. Res., 38, 1206, doi:10.1029/2001WR000760.

Moradkhani, H., and M. Meier, 2010: Long-lead water supply forecast using large-scale climate predictors and independent component analysis. J. Hydrol. Eng., 15, 744-762, doi:10.1061/ (ASCE)HE.1943-5584.0000246.

Morrison, J., M. C. Quick, and M. G. Foreman, 2002: Climate change in the Fraser River watershed: Flow and temperature projections. J. Hydrol., 263, 230-244.

Najafi, M., H. Moradkhani, and S. Wherry, 2010: Statistical downscaling of precipitation using machine learning with optimal predictor selection. J. Hydrol. Eng., doi:10.1061/(ASCE)HE.19435584.0000355 .

Raftery, A. E., T. Gneiting, F. Balabdaoui, and M. Polakowski, 2005: Using Bayesian model averaging to calibrate forecast ensembles. Mon. Wea. Rev., 133, 1155-1174.

Rundel, P. W., D. J. Parsons, and D. T. Gordon, 1977: Montane and subalpine vegetation of the Sierra Nevada and Cascade ranges. Terrestrial Vegetation of California, M. G. Barbour and J. Major, Eds., Wiley, 559-599.

Stewart, I. T., D. R. Cayan, and M. D. Dettinger, 2004: Changes in snowmelt runoff timing in western North America under a 'business as usual' climate change scenario. Climatic Change, 62, 217-232.

Walker, J. F., and T. D. Bullen, 2000: Trout Lake, Wisconsin: A water, energy, and biogeochemical budgets program site. U.S. Geological Survey Rep. 161-99, 4 pp.

Washington, W. M., and Coauthors, 2000: Parallel Climate Model (PCM) control and transient simulations. Climate Dyn., 16, 755-774.

Wolock, D. M., and G. J. McCabe, 1999: Estimates of runoff using water-balance and atmospheric general circulation models. J. Amer. Water Resour. Assoc., 35, 1341-1350.

Earth Interactions is published jointly by the American Meteorological Society, the American Geophysical Union, and the Association of American Geographers. Permission to use figures, tables, and brief excerpts from this journal in scientific and educational works is hereby granted provided that the source is acknowledged. Any use of material in this journal that is determined to be "fair use" under Section 107 or that satisfies the conditions specified in Section 108 of the U.S. Copyright Law (17 USC, as revised by P.IL. 94553) does not require the publishers' permission. For permission for any other from of copying, contact one of the copublishing societies. 
Copyright of Earth Interactions is the property of American Meteorological Society and its content may not be copied or emailed to multiple sites or posted to a listserv without the copyright holder's express written permission. However, users may print, download, or email articles for individual use. 